Florida International University

FIU Digital Commons

FIU Electronic Theses and Dissertations

University Graduate School

3-25-2009

\title{
Buddha and Moses as primordial saints: a new typology of parallel sainthoods derived from Pali Buddhism and Judaism
}

Upananda Thero Dedunupitiye

Florida International University

DOI: $10.25148 /$ etd.FI14062231

Follow this and additional works at: https:// digitalcommons.fiu.edu/etd

Part of the Buddhist Studies Commons, and the Comparative Methodologies and Theories Commons

\section{Recommended Citation}

Dedunupitiye, Upananda Thero, "Buddha and Moses as primordial saints: a new typology of parallel sainthoods derived from Pali Buddhism and Judaism" (2009). FIU Electronic Theses and Dissertations. 2761.

https://digitalcommons.fiu.edu/etd/2761 
Miami, Florida

\section{BUDDHA AND MOSES AS PRIMORDIAL SAINTS: A NEW TYPOLOGY OF PARALLEL SAINTHOODS DERIVED FROM PALI BUDDHISM AND JUDAISM}

A thesis submitted in partial fulfillment of the requirements for the degree of MASTER OF ARTS in

RELIGIOUS STUDIES

by

Upananda Thero Dedunupitiye

2009 
To: Dean Kenneth Furton

College of Arts and Sciences

This thesis, written by Upananda Thero Dedunupitiye, and entitled Buddha and Moses as Primordial Saints: A New Typology of Parallel Sainthoods Derived from Pali Buddhism and Judaism, having been approved in respect to style and intellectual content, is referred to you for judgment.

We have read this thesis and recommend that it be approved.

Oren Baruch Stier

Albert Wuaku

Nathan Katz, Major Professor

Date of Defense: March 25, 2009

The thesis of Upananda Thero Dedunupitiye is approved.

Dean Kenneth Furton College of Arts and Sciences

Dean George Walker University Graduate School

Florida International University, 2009 
(C) Copyright 2009 by Upananda Thero Dedunupitiye All rights reserved. 


\section{DEDICATION}

I dedicate this thesis to my late father, Udalagama Walawwe Seneviratna

Udalagama, late mother, Podimenike Wijekoon Udalagama, late preceptor, the Right Reverend Wahakula Sri Somananda Mahathera, and to my monastic guru, the Right Reverend Kariyagama Gunananda Mahathera, who taught me the way to live my life. 


\section{ACKNOWLEDGMENTS}

I deeply thank the members of my MA thesis committee, Dr. Nathan Katz, Dr. Oren Baruch Stier and Dr. Albert Wuaku, and Head of the FIU Department of Religious Studies, Dr. Christine Gudorf, the Department Secretary, Mrs. Mireille Sylvain-David, and Miss. Liz Perez, Technical Assistant and Assistant Secretary to the FIU Department of Religious Studies, for their compassion, caring, guidance and for being a great source of encouragement.

I express my deepest gratitude to Florida International University for granting me an invaluable opportunity to accomplish a goal in my academic life, which I had always dreamt of.

Last but not least, I express my deepest thanks and gratitude to the Reverend Sudarshana Peliyagoda, Abbess of Samadhi Buddhist Meditation Center, Pinellas Park, Florida, and Mrs. Huey Adams of Clearwater, Florida, who are my immigration and financial sponsors in the United States. 


\begin{abstract}
OF THE THESIS
BUDDHA AND MOSES AS PRIMORDIAL SAINTS: A NEW TYPOLOGY OF

PARALLEL SAINTHOODS DERIVED FROM PALI BUDDHISM AND JUDAISM by
\end{abstract}

Upananda Thero Dedunupitiye

Florida International University, 2009

Miami, Florida

Professor Nathan Katz, Major Professor

Comparative studies in sainthood in world religions, especially Pali Buddhism and Judaism has been a substantial component of my academic interests. Constructed out of my research findings the new typology of sainthood lays emphasis on the fact the two religions have a common universal pattern of sainthood, hence parallel sainthoods.

My research concludes that Siddhartha the Buddha and Moses the Prophet as primordial saints, as saintliness as a human quality in Pali Buddhism and Judaism originates from these personalities. Any other successive types of sainthood in the said religious traditions are derived from the main type, the primordial sainthood. 
TABLE OF CONTENTS

CHAPTER

PAGE

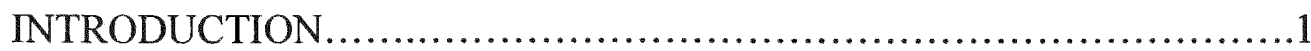

1.LINKED FOCI AND SAINTOHOOD IN THE

PERIPHERY .............................................................. 7

The Linked Foci........................................................... 7

Sainthood in the Periphery ..............................................

2.THE THORETICAL APPROACH....................................14

The Orientalist/Eurocentric Scholarship on Pali Buddhism...................14

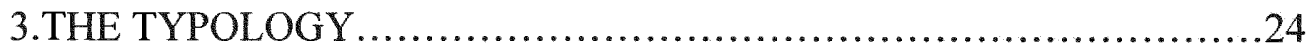

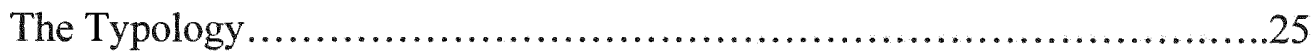

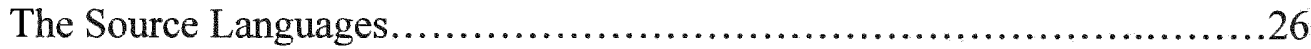

The Pali terms and their Etymology ......................................26

Comparative Terminology ...............................................28

Siddhartha the Buddha and Moses the Prophet: The

Comparative Case...........................................................29

Successive Sainthoods of Pali Buddhism....................................32

Successive Sainthoods of Judaism......................................37

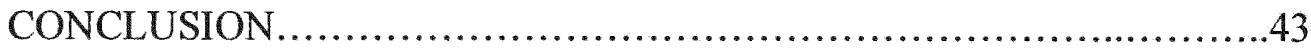

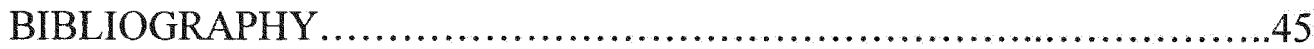




\section{INTRODUCTION}

The research project, titled "Buddha and Moses as Primordial Saints: A New Typology of Parallel Sainthoods Derived from Pali Buddhism and Judaism," contextualizes the Buddha of Pali Buddhism as the "Primordial Buddhist Saint," and identifies Moses of Judaism as the "Primordial Jewish Saint" in comparison with the Buddha. The study contextualizes Buddha and Moses as the "first-ever saints" of the religions they belong to. The term "primordial" in this study strictly means "first-ever." Buddha and Moses are "primordial saints" as they have "pioneered" sainthood in their respective religions. The study is limited to Buddha as depicted in Pali Buddhism, and to Moses in Judaism. These two religious personalities are also depicted in other Buddhist traditions and other Abrahamic religions, i.e. Christianity and Islam.

Here, I would like to explain my thesis argument of primordial sainthood. I argue that sainthood is essentially a human characteristic. Of the Abrahamic religions ${ }^{1}$, the Christian religion has the richest tradition of sainthood. In Christian religion, all the saints are human beings beatified by the Pope, who is a human agent of God. Individuals as well as different denominations of this religion have patron saints that are said to bless and protect the believers. Even though Christian saints are considered divine, fundamentally they were human beings before their elevation to sainthood.

\footnotetext{
'Judaism, Christianity and Islam are the Abrahamic religions, as all of them accept the idea that Abraham is the forefather of chosen people.
} 
The study seeks to explain the nature of primordial sainthood in the context of Pali Buddhism and Judaism. I will give a brief history of modern scholarship on sainthoods in the religious traditions involved, because it provides my study with background knowledge that I find necessary in order to contextualize the idea of primordial saint. In order to avoid repetition, an in-depth description of the background to sainthood is not given here. It will be discussed at length throughout the study.

A clarification of my thesis argument on primordial saint is necessary here, as the primordial saint is a new concept. The concept of sainthood in world religions is complex in definition and character, due to the fact that sainthood varies from religion to religion. Derived from the Latin word, "Sanctus" meaning "holy, consecrated," the term "saint" connotes "holy person." A holy person is one who serves as an exemplar of virtue and embodiment of sacred power, for instance, an Arahant in Buddhism, and a Zaddik in Judaism. The holy person lives according to the highest ideals of a religious tradition. Such life might involve rigorous asceticism, profound exposition of doctrine, prophetic or mystical experience, or martyrdom. The result of such a life is the achievement of the ultimate goal as defined by that tradition, such as salvation for a Jew or Nirvana for a Buddhist.

In Pali Buddhism, the Buddha is a human being, who appears after the destruction of each cycle of human civilization, and guides humanity towards salvation. Unless he manifests, the path to salvation is nowhere to be discovered. In Judaism, the salvation of

\footnotetext{
${ }^{2}$ Jonathan Smith, The HarperCollins Dictionary of Religion, ed. William S. Green (New York: Harper San Francisco, 1998) pg. 461.
} 
human beings depends on God. In theistic religions like Judaism, it is always a human being who is chosen by God to give the Revelation. Moses is the chosen individual in Judaism. On the human level, therefore, Moses is the first human being to hear, record and pass down the revelation to future revelation. In both religions, therefore, the human personalities of Buddha and Moses have pioneered the path of salvation on human level. Because of this role, I define Buddha and Moses as primordial saints. Their holiness is either God-given or self-earned. Buddha's holiness is self-earned, whereas Moses' holiness is God-given. The term God-given is not to be understood as given by God but originated out of God's choice. Following the paths of salvation Buddha and Moses have shown, latter day followers of Judaism and Pali Buddhism could tread the paths of salvation whereby they could become saintly. This saintliness thus occupied by them entails my notion of successive sainthoods. The notion of successive sainthood is so called, as they depend on the primordial sainthood. In other words, unless Buddha and Moses brought the revelations to the human level, no human being would have been able to become a saint or saint-like. The idea of successive sainthoods validates and strengthens the idea of primordial sainthood.

A brief introduction to the religious traditions involved is necessary here in order to indicate the limits of the research area. Pali Buddhism, which is the Buddhist tradition involved, is synonymous with Theravada Buddhism. Pali is a sixth century $\mathrm{BCE}$, middle Indo-Aryan language in which the historical Buddha, Siddhartha Gautama, is believed to have carried out his mission in India. Theravada means "doctrine (vada) of the Elders or earliest Buddhist monastic's (thera). In the South Asian region, Theravada Buddhism is 
predominant in Sri Lanka, which has become the stronghold of Pali Buddhism with its decline in India. Another place where Theravada is predominant is the Southeast Asian region. In this region, it is predominantly present in Burma (Myanmar), Cambodia, Laos, and Thailand. Theravada is highly assimilated with local beliefs in each of these countries. Fundamentally, I will only use the trend of Theravada Buddhism depicted in the Pali canon in order to avoid terminological ambiguity. This includes both canonical and Sri Lankan popular Theravada, both of which are based on the Pali canon. The other religious tradition, Judaism, is considered in general. In my study, Pali Buddhism is the major religion tradition of comparison, whereas Judaism is the minor religious tradition. The typology of primordial sainthood is first derived from Pali Buddhism and then viewed and compared to its Jewish counterpart. The process involves the study of modern scholarship on Buddhist and Jewish sainthoods, and the construction of the typology of primordial sainthood together with the successive sainthoods.

The definitions of saint or holy person explained above correspond, more or less, to both Buddha and Moses. Viewed from an academic standpoint, saints are always human personalities. They are sacred in the human world.

Siddhartha and Moses were actual historical figures. In the case of Pali Buddhist primordial sainthood, a historical human figure, Siddhartha Gautama is identified with the theological position of Buddha. Moses a historical human figure is identified with the theological position of Prophet. Siddhartha became an extraordinary man, because of his "self-revelation" of the truth. 
There is considerable modern scholarship on Buddhist and Jewish sainthoods. Since 1913, there have been a number of western scholars writing on Pali Buddhist sainthood. Rhys Davids, an Orientalist, writing in 1913, defined Buddhist sainthood as a "standard of exceptional values and satisfactions for the enlightened Buddhists" (arahants). He only sees arahant as saint, and therefore, his definition is exclusive. In 1984, Stanley J. Tambiah made the biggest- ever contribution to the scholarship on Pali Buddhist sainthood with his theory of "Linked Foci.", George D. Bond further elaborates the notion of Pali Buddhist sainthood with reference to Tambiah's theory. ${ }^{4}$

Meanwhile, scholars of Judaism have employed the term "saint" on numerous occasions in the history of Jewish scholarship. For example, Solomon Schechter in 1908 wrote on the concept of Jewish sainthood. ${ }^{5}$ He considers the term, "Chasid" as the best Hebrew equivalent for the term saint. An adjective, it is commonly used in the sense of "pious," "devout," "reverend," or "godly." It implies the qualities of a saint, such as grace, graciousness, and kindness. I use Richard Cohen's idea of "sainthood in periphery"7 in order to examine position of Jewish parallels of sainthood.

\footnotetext{
${ }^{3}$ See Stanley J. Tambiah, The Buddhist Saints of the Forest and the Cult of Amulets: A Study in Charisma, Hagiography, Sectarianism and Millenial Buddhism (New York: Cambridge UP, 1984).

${ }^{4}$ See George D. Bond, "The Arahant: Sainthood in Theravada Buddhism," Sainthood - Its Manifestations in World Religions, ed. Richard Kieckhefer and George D. Bond (New York: University of California P, 1992) pg. 140-171.

${ }^{5}$ See Solomon Schechter, Studies in Judaism: Essays on Persons, Concepts, and Movements of Thought in Jewish Tradition, 3rd Reprint ed. (Atheneum, NY: The Jewish Publication Society of America, 1970).

${ }^{6}$ Solomon Schechter, Studies in Judaism: Essays on Persons, Concepts, and Movements of Thought in Jewish Tradition, 3rd Reprint ed. (Atheneum, NY: The Jewish Publication Society of America, 1970) pg. 125.

${ }^{7}$ Robert L. Cohn, "Sainthood on the Periphery," Sainthood - Its Manifestations in World Religions, by Richard Kieckhefer, ed. George D. Bond (New York: University of California P, 1992) pg. 43-68.
} 
The thesis will be organized in three chapters. Chapter One examines the Pali Buddhist and Jewish theories of sainthood. Chapter Two will discuss the Indo-Judaic approach as the Method of Study. Chapter Three will reveal and construct the Typology and work towards the concept of a Buddhist Primordial Saint and Successive Sainthoods.

Chapter One will examine Tambiah's theory of Linked Foci, and Richard Cohn's theory of Sainthood in the Periphery. Chapter Two is dedicated to explain the Indo-Judaic approach of "What-Aspect" and "What-So-Aspect," the very research method I employ. Chapter Three contextualizes the notion of primordial saint. It also constructs a notion of successive saints that further strengthens and validates the notion of primordial saint. The study will end with the conclusion.

As for the sources, I use both original Pali sources and modern scholarship to contextualize the notion of primordial sainthood in Pali Buddhism, while available modern scholarship on Judaism is used together with occasional reference to Jewish canonical terms, available in Hebrew and English. 


\section{CHAPTER ONE \\ LINKED FOCI AND SAINTHOOD IN THE PERIPHERY}

The chapter revisits the theory of "Linked Foci" of Stanley Tambiah, and the theory of "Sainthood in the Periphery" of Richard Cohn. The theory provides my study with the necessary theoretical background for the typology of primordial saint.

His extensive knowledge in anthropology of Theravada (Pali) Buddhism in South and Southeast Asia has helped him deconstruct the Pali Buddhist canon and commentaries thereof to construct the theory of "linked foci."

\section{The Linked Foci}

Below is a discussion of Tambiah's theory concerning "linked foci," together with its translation in English. The first entry given in Pali is the original. The second entry is by the author's translation:

(1) Samsara/Nibbana

Dukkha/Nirodha

Lokiya/Lokuttara

Avijja/Panna ${ }^{8}$

(2) Cycle of Birth and Death/Nirvana or Salvation

Suffering/End of Suffering

Mundane/Transcendental

Ignorance/Wisdom

\footnotetext{
${ }^{8}$ Stanley J. Tambiah, The Buddhist Saints of the Forest and the Cult of Amulets: A Study in Charisma, Hagiography, Sectarianism and Millenial Buddhism (New York: Cambridge UP, 1984) pg. 346.
} 
Tambiah derives the linked foci from the Pali Buddhist concept of Truth (sacca), which is twofold, "sammuti sacca," or "apparent truth," and "paramattha sacca," or "absolute truth." The linked foci are comprised of four pairs of realities. Of each pair, the first is part of the apparent truth, and the second, the absolute truth.

As an average man gets enlightened, he goes through a shift in his ordinary way of thinking. Pali Buddhism calls it a "cognitive shift." It is called a cognitive shift, as enlightenment is shift in the cognition of human beings. Despite his enlightenment, he still perceives himself and the outside world through his sense faculties, or "indriyas." But, his perception is free from what is called "attachment," or "raga." He, therefore, remains unperturbed and unaffected by the world. At his enlightenment, he totally and permanently ceases to be affected by the 'apparent truth.' This happens, thanks to his realization of the "absolute truth." The twofold truth is well explained in the Abhidhamma. ${ }^{9}$ According to the Abhidharma, only four categories of things namely, (1) mind (consciousness), (2) mental concomitants (=thoughts +memories + emotions +tendencies), (3) materiality and (4) Nirvana are classed as the Ultimate Truth. All the rest are regarded as apparent truth.

When such expressions as 'I', 'you', 'man', 'woman', 'person', 'individual', are used, we are speaking about things that do not exist in reality. By using such expressions about things that exist only in designation, we are not telling a lie; we are merely articulating an apparent truth. To an ordinary human being there is no difference between

\footnotetext{
${ }^{9}$ The Pali Buddhist canon (Tipitaka) comprised of three divisions (pitakas), one of which is Abhidhamma, or the division of metaphysical teachings or psychology.
} 
the two levels of truth, since to him the ultimate truth is just another concept. He only conceptualizes the absolute truth based on the revelation of Buddha. Unless an individual is enlightened, the Buddha's "experiential knowledge" of salvation is merely "theoretical knowledge" in the eyes of an ordinary individual. The presence of Buddha therefore is mandatory for ordinary human beings to experience salvation. Upon achieving salvation, ordinary human beings become "arahnats." From that point on, their knowledge is no longer theoretical but experiential.

Tambiah considers all the categories of enlightened persons in Buddhism as Arahants. The term, which is derived from the Pali term "arahanta," denotes "one who has ended all defilements or negative mental tendencies that create suffering. ${ }^{10}$

The way an enlightened person, or Arahant, focuses on himself and the world originates from his realization of the absolute truth. An average, unenlightened man focuses on himself and the world in light of sensory knowledge that is imperfect. The focus of the enlightened and that of the unenlightened are not two separate things; they are two different levels of the same human mind.

Using Tambiah's linked foci, Bond concludes that an Arahant has a dual nature. He has transcended the world, and is part of the world simultaneously, because he still remains in the world.

\footnotetext{
${ }^{10}$ Verse 90: For an arahant, so called, as his journey is ended, who is free from sorrow and from all (e.g. khandha aggregates), who has destroyed all fetters, there is no more distress. See Hinuber O. Von and K R Norman, eds., The Dhammapada (London: Pali Text Society, 1994).
} 
In Pali Buddhism, salvation is a living experience, and not an after-life or otherworldly situation.

In Tambiah's words, the way an Arahant differs from an average man is grounded in the linked foci. In Bond's words, an Arahant's transcending of the world, while remaining in the world is the "dual nature of Arahant." "Even though the focus changes from "what" to "what exactly," as one becomes an Arahant, a link between the foci remains. According to Pali Buddhism, it is the role of a Buddhist saint that he guides the society or the world, while remaining in the world. The Dhammapada mentions that the Buddha is a guide, and self-purification is the duty of individual followers. ${ }^{12}$

In his work ${ }^{13}$ Tambiah contextualizes two types Thai Theravada saints, forest saints, and saints of the cult of amulets. While the first type represents those adhering to the classical Buddhist practice, the second type represents popular Buddhist saints. However, he separates popular saints from the Arahants, owing to his Eurocentric/Orientalist approach. Amulets are widely used in Thai Theravada Buddhism as a blessing and healing device. The second type he contextualizes does not necessarily fall within the second half of the Linked Foci. Tambiah does not directly say whether one can be a saint but not an Arahant. From the Indo-Judaic approach, no doubt as such

\footnotetext{
${ }^{11}$ George D. Bond, "The Arahant: Sainthood in Theravada Buddhism," Sainthood - Its Manifestations in World Religions, ed. Richard Kieckhefer and George D. Bond (Berkeley: University of California Press, 1992) pg. 168.

${ }^{12}$ Verse 276:"Tumhehi kiccam atappam - akkhataro tathagatha"- See Hinuber O. Von and K R Norman, eds., The Dhammapada (London: Pali Text Society, 1994).

${ }^{13}$ See Stanley J. Tambiah, The Buddhist Saints of the Forest and the Cult of Amulets: A Study in Charisma. Hagiography, Sectarianism and Millenial Buddhism (New York: Cambridge UP, 1984).
} 
arises. Tambiah's "Linked Foci" helps us understand Cohn's "Sainthood in the

Periphery," which will be examined in the next chapter, as both scholars maintain that the two religions do have at least a notion of a "holy person" that is not necessarily called "saint."

\section{Sainthood in the Periphery}

As mentioned in the introduction, scholars of Judaism have used the term "saint" on numerous occasions. Yet, it was only in the 1990 s that Robert L. Cohn contributed a more comprehensive theory of Jewish sainthood. As a scholar of comparative religion he breaks grounds for further studies in Jewish sainthood. His contribution to a 1990 publication on comparative sainthood, "Sainthood: Its Manifestations in World Religions," 14 constructs his idea of "sainthood on the periphery." Cohn states that the mention of the term "saint" to a Jew likely causes bewilderment to him. The reason is that the term conjures up images of halos, shrines and relics. ${ }^{15}$

He hints at biblical prophets, such as Abraham, Moses, etc., being concluded to be saints of Judaism. His use of the term "bewilderment" is due to the universal fact that Judaism in general does not teach the veneration or worship images, halos, shrines, and personality cults.

\footnotetext{
${ }^{14}$ See Robert L. Cohn, "Sainthood on the Periphery," Sainthood - Its Manifestations in World Religions, by Richard Kieckhefer, ed. George D. Bond (New York: University of California P, 1992) pp. 43-68.

${ }^{15}$ Ibid., p. 43
} 
Even though Buddhism does have such things, it still does not use the term "saint." Cohn is of the view that, for western Jews, the idea of sainthood is a category that is irredeemably Christian. ${ }^{16}$ So is the mentality of a Buddhist. A Buddhist might get bewildered, if he is asked whether he believes in or worship saints. In both cases, the problem of accepting the notion of saints is purely linguistic but not necessarily cultural or religious. Buddhists and Jews do not use the term "saint." Yet, they venerate or, in more general terms, respect "holy persons." Cohn neither accepts nor rejects the Jewish tendency of "revering holy persons" (= venerating or worshipping saints"). However, he concludes that Judaism does not "revere" "exceptional human beings" but rather sets forth "ideals of learning." "17

The term "ideals of learning" embodies the essence of Jewish sainthood. Cohn explains the term in light the theology of Judaism. In Judaism salvation is not primarily an individual but a group achievement. Judaism sees the notion of saint as presupposing an individualistic form of piety. The saint, as Cohn assumes, is a spiritual leader who has cultivated a unique path and can help his followers cultivate theirs. Cohn makes a remarkable point that Jews lack the need for an individuals' intercession between them and God, because salvation (=redemption) comes only when society as a whole is ripe for it. ${ }^{18}$ Accordingly, Judaism does not seem to be interested in having individual saints. God

\footnotetext{
${ }^{16}$ Robert L. Cohn, "Sainthood on the Periphery," Sainthood - Its Manifestations in World Religions, by Richard Kieckhefer, ed. George D. Bond (New York: University of California P, 1992) pg. 43.

${ }^{17}$ Robert L. Cohn, "Sainthood on the Periphery," Sainthood - Its Manifestations in World Religions, ed. by Richard Kieckhefer, and George D. Bond (New York: University of California P, 1992) pg.65.

${ }^{18}$ Ibid., 45.
} 
will grant salvation to all the Jewish people. The "ideals of learning" that people (Jews) turn to for learning include figures that could be considered saints or holy persons, too. Cohn gives an extensive account of how in different branches of Judaism, such as mysticism, people follow holy persons. ${ }^{19}$ In his extensive account of "Saint-like Manifestations in Jewish History" Judaism, at least, in Jewish mysticism, certain personalities, such as Jewish mystics, become objects of reverence.

${ }^{19}$ Robert L. Cohn, "Sainthood on the Periphery," Sainthood - Its Manifestations in World Religions, ed. by Richard Kieckhefer, and George D. Bond (Berkley: University of California P, 1992) pg.45. 


\section{CHAPTER TWO \\ THE THEORETICAL APPROACH}

The chapter examines the nature of the Orientalist/Eurocentric theoretical approach that has been applied in the study of Pali Buddhism by various scholars, and the applicability of the Indo-Judaic approach I employ in my study. First, the first approach is examined, as it gives the necessary understanding in order to look at the Indo-Judaic approach.

\section{The Orientalist/Eurocentric Scholarship on Pali Buddhism}

Orientalism is an ideological mode used by European scholars in examining nonEuropean civilizations. Subsequently, both "Orientalist" and "Eurocentric" constitute a single ideological mode. ${ }^{20}$. There were exchanges between the East and West of knowledge and perception of each other from early times. These exchanges structured European views of the "Other" of Europe. From very early times, Sri Lanka was at the crossroads of this global East-West traffic in perceptions. ${ }^{21}$ There have been many Orientalist/Eurocentric scholars of comparative religion studying Pali Buddhism in Sri Lanka.

It was British colonialism that paved the way for them to go to Sri Lanka, the center of Pali Buddhism. Goonatilake mentions four prominent Orientalist/Eurocentric scholars. They are Richard Gombrich, Gananath Obeysekera, Bruce Kapferer and Stanley J Tambiah. Obeysekera and Tambiah are ex-Sri Lankans who have worked in Europe and

\footnotetext{
${ }^{20}$ Susantha Goonatilake, Anthropologizing Sri Lanka A Eurocentric Misadventure (New York: Indiana UP, 2001) pg. xi

${ }^{21}$ For an extensive account of the European perception of Sri Lanka, especially in the area of Pali Buddhism, see Susantha Goonatilake, "Contextualizing the Anthropology of Sri Lanka," Anthropologizing Sri Lanka A Eurocentric Misadventure (New York: Indiana UP, 2001) pg. 4-28.
} 
America practicing this Eurocentric art. ${ }^{22}$ The other two, Gombrich and Kapferer, are Britishers working in Britain and Australia. The universities they cover include key intellectual centers in the West: Oxford (Gombrich), Cambridge (Obeysekera), Princeton (Obeysekera), Harvard (Tambiah), and London (Kapferer). ${ }^{23}$ Gombrich delineates the precepts and doctrines of Buddhism. Goonatilake hints at Gombrich operating within a Eurocentric framework, which occasionally comes to the surface in the questions the latter asks and the statements he makes. Gombrich states that, as the Buddha is dead, the problem is raised in the Western mind (meaning his own) "about places filled and functions performed by the Christian God. ${ }^{24}$ This is due to the fact that the Eurocentric/Orientalist model is reductionist. It connects the Buddhist idea of "enlightenment" or "Nirvana" to the supernatural, and reduces the lower levels of spirituality to the folk level thereby separating the latter from the former. Gombrich and Obeysekera delineate two aspects of the Sinhalese Buddhism. One deals with "salvation" according to Buddhism, and the other with "spirit religion," the irrational. ${ }^{25}$ The spirit religion here is nothing but the popular Pali Buddhism in Sri Lanka. Kapferer delineates enlightenment/Nirvana and what he calls "exorcism," 26 which is "spirit religion" or

\footnotetext{
${ }^{22}$ Susantha Goonatilake, Anthropologizing Sri Lanka A Eurocentric Misadventure (New York: Indiana UP, 2001) pg. xii

${ }^{23}$ Ibid

${ }^{24}$ Richard F. Gombrich, Buddhist precept and practice traditional Buddhism in the rural highlands of Ceylon (London: Kegan Paul International, Distributed by Columbia UP, 1995) pg. 168.

${ }^{25}$ Richard Gombrich and Gananath Obeysekera, Buddhism Transformed: Religious Change in Sri Lanka (Princeton, NJ: Princeton UP, 1988) pg. xi.

${ }^{26}$ See Bruce Kapferer, Celebration of demons exorcism and the aesthetics of healing in Sri Lanka (Providence, R.I., USA: Berg, Smithsonian Institution P, 1991).
} 
"practice," as Gombrich and Obeysekera call it. Tambiah delineates

enlightenment/Nirvana and "nationalism." Nationalism here represents what the other scholars term as practice, spirit religion, etc. ${ }^{27}$

\section{From Two-Wheel Theory to One-Wheel Theory}

Nathan Katz and Stephen D. Sowle explain the Orientalist/Eurocentric reductionism of Pali Buddhism with reference to two theories of Buddhism, "Two-Wheel Theory" and "One-Wheel Theory," with reference to the Pali canon as well as some Eurocentric scholars. ${ }^{28}$ They are Melford Spiro and Winston King. ${ }^{29}$ Their discussion is based on a popular dichotomy of Nibbanic Buddhism and Kammic Buddhism. Spiro and King take their lead from Max Weber, who said of the Buddhist notion of "salvation" that is not sought through proving one's self by any inner-worldly or extra-worldly action, by "work" of any kind, but in contrast to this, it is sought in a psychic state remote from activity. This is decisive for the location of the "arahat (arahant) ideal" with respect to the "world of rational action." "No bridge connects them." Nor is there any bridge to any actively conceptualized social conduct. Salvation is absolutely personal performance of the self-reliant individual. No one, and particularly no social community can help him.

${ }^{27}$ Susantha Goonatilake, Anthropologizing Sri Lanka A Eurocentric Misadventure (New York: Indiana UP, 2001) pg. 215-219.

${ }^{28}$ See Nathan Katz and Stephen D. Sowle, "Theravada Buddhism and Marxism in the Postwar Era," Movements and Issues in World Religions: A Sourcebook of Developments since 1945, ed. Charles Weihsun and Gerhard E. Spiegler (New York, Westport, CT, and London: Greenwood P, 1987) pg. 418-462.

29 Also see Frank Reynolds, "The Two Wheels of Dhamma: A Study of Early Buddhism," The Two Wheels of Dhamma: Essays on Theravada Tradition in India and Ceylon, vol. Three (Chambersburg, Pennsylvania: American Academy of Religion, 1972) pg. 6-30 
The specific asocial character of all genuine mysticism is here carried to its maximum. ${ }^{30}$ According to the dichotomy, the entire Buddhism ${ }^{31}$ is divided into two distinct, even contradictory, ethical fields: nibbanic Buddhism that is for those spiritually advanced practitioners seeking enlightenment and escape from rebirth through the cultivation of detachment; and kammic Buddhism that is ethically normative for the vast majority of Buddhists and has its soteriological goal better rebirth in human or heavenly realms. ${ }^{32}$ According to the two-wheel theory, the higher level of Buddha/Arahant/ nirvana/ enlightenment/supernatural/ precept/salvation, etc. is one wheel, and the lower level of Buddhist followers/ heaven/the social conduct/ practice/ritual, etc. is the other wheel. An Indo-Judaic scholar, Katz supports the one-wheel theory. ${ }^{33}$ He challenges Spiro and King's understanding of Pali Buddhist sources. To Katz the Eurocentric twowheel theory is a "disjunction" of Buddhism, which in fact is a "fundamental continuity" in his terms. Katz argues that the Buddhist terms "kusala" and "punna" (roughly parallel to Spiro and King's distinction between nibbanic and kammic Buddhism) do not refer to two distinct realms of ethical activity, but rather form "one continuous spectrum" that

\footnotetext{
${ }^{30}$ Max Weber, The Religions of India (Glencoe, Ill: Free P, 1958) pg. 213; quoted in Nathan Katz and Stephen D. Sowle, "Theravada Buddhism and Marxism in the Postwar Era," Movements and Issues in World Religions: A Sourcebook of Developments since 1945, ed. Charles Wei-hsun and Gerhard E. Spiegler (New York, Westport, CT, and London: Greenwood P, 1987) pg. 417.

${ }^{31}$ Weber, Spiro and King refer to Pali Buddhism, as Kamma and Nibbana are the Pali cognates of Sanskrit Karma and Nirvana. Indian Buddhism that Weber refers to is the version based on the Indian language of Pali.

32 Nathan Katz and Stephen D. Sowle, "Theravada Buddhism and Marxism in the Postwar Era," Movements and Issues in World Religions: A Sourcebook of Developments since 1945, ed. Charles Weihsun and Gerhard E. Spiegler (New York, Westport, CT, and London: Greenwood P, 1987) pg. 417-418.

${ }^{33}$ See Nathan Katz, Buddhist Images of Human Perfection The Arahant of the Sutta Pitaka Compared with the Bodhisattva and the Mahasiddha (Delhi: Motilal Banarsidass Pub, 2004).
} 
unites monastic and lay activity in one system. ${ }^{34}$ Here, monastic activity is what the previously mentioned Eurocentric scholars include in the higher level, and the lay activity, in the lower level. Punna, which refers to meritorious kammic activity having pleasing results, is presented in the Pali suttas as the "habituating ground" of kusala, which describes the activity of the Buddha or an arahant and activity that has no result of action (Pali: kammaphala). ${ }^{35} \mathrm{Katz}^{36}$ and Harvey B. Aronson ${ }^{37}$ give extensive descriptions of Pali Buddhist terms in support of the one-wheel theory, which underpins Pali Buddhism from the Indo-Judaic approach. The primordial saint as well as the two successive saints, saint of the word, and saint of the people are part of the fundamental continuity of Pali Buddhist ethical activity.

I now examine the theoretical underpinning of the Indo-Judaic approach. My research is based on two different religious traditions, Pali Buddhism and Judaism. Pali Buddhism is a religious tradition, native to the Indian subcontinent that is the landscape of ancient Indus-Valley civilization. Its counterpart, Judaism, is the first and foremost religious tradition of the ancient Jewish civilization. A fast-emerging field of comparative research, the Indo-Judaic studies, underpins my research, as the field's focus is these two religious traditions. A description of the inception of the field is given here, as it

\footnotetext{
${ }^{34}$ Nathan Katz and Stephen D. Sowle, "Theravada Buddhism and Marxism in the Postwar Era," Movements and Issues in World Religions: A Sourcebook of Developments since 1945, ed. Charles Weihsun and Gerhard E. Spiegler (New York, Westport, CT, and London: Greenwood P, 1987) pg. 419.

${ }^{35}$ Ibid

${ }^{36}$ See Nathan Katz, Buddhist Images of Human Perfection The Arahant of the Sutta Pitaka Compared with the Bodhisattva and the Mahasiddha (Delhi: Motilal Banarsidass Pub, 2004).

${ }^{37}$ See Harvey B. Aronson, Love and Sympathy in Theravada Buddhism (Delhi: Motilal Banarsidass Pub, 1980) pg. 78-96.
} 
illustrates the way the field has come into being, and how my research theoretically fits in this field. The following chart of illustration is based on the Nathan Katz's contribution to the Journal of Indo-Judaic Studies, which is the academic voice of the field. ${ }^{38}$

(The chart is moved to the next page, owing to its size.)

${ }^{38}$ See "Indo-Judaic Studies as a field" in Nathan Katz, "Introduction," Indo-Judaic Studies in the TwentyFirst Century A View from the Margin (New York: Palgrave Macmillan, 2007) pg. 2-4. 


\begin{tabular}{|c|c|c|}
\hline \multicolumn{3}{|c|}{$\begin{array}{l}\text { The Field of Indo-Judaic Studies } \\
\text { (The name is derived from Hebrew-Sanskrit }>\text { Hindu-Jewish }>\text { Hindu- } \\
\text { Judaic }>\text { Indo-Judaic) }\end{array}$} \\
\hline $\begin{array}{l}\text { Sub-areas of the Indo- } \\
\text { Judaic Studies }\end{array}$ & Indian Civilization & Jewish Civilization \\
\hline Religious/Cultural & $\begin{array}{l}\text { Hinduism, Pali } \\
\text { Buddhism and Indian } \\
\text { religious and cultures }\end{array}$ & $\begin{array}{l}\text { Judaism and other } \\
\text { Abrahamic and middle } \\
\text { eastern religions and } \\
\text { culture (Christianity, } \\
\text { Islam, Bahai, etc.) }\end{array}$ \\
\hline Linguistic & $\begin{array}{l}\text { Sanskrit and other } \\
\text { Indian languages, such } \\
\text { as Pali and Tamil }\end{array}$ & $\begin{array}{l}\text { Hebrew and other } \\
\text { relative languages such } \\
\text { as Aramaic used since } \\
\text { Asokan period in India }\end{array}$ \\
\hline Diaspora & $\begin{array}{l}\text { Indian Jewish } \\
\text { communities such as } \\
\text { Kochin, Baghdadi and } \\
\text { Bene Israel }\end{array}$ & $\begin{array}{l}\text { Indian Jewish migrants } \\
\text { in Israel }\end{array}$ \\
\hline Trade & $\begin{array}{l}\text { India's trade links } \\
\text { with Jews, ancient and } \\
\text { modern }\end{array}$ & $\begin{array}{l}\text { Jewish trade links with } \\
\text { India, ancient and } \\
\text { modern }\end{array}$ \\
\hline $\begin{array}{l}\text { Political/diplomatic } \\
\text { relations }\end{array}$ & $\begin{array}{l}\text { End of British rule of } \\
\text { India and the birth of } \\
\text { sovereign India in } \\
\text { 1947, and start of } \\
\text { diplomatic relations } \\
\text { with Israel }\end{array}$ & $\begin{array}{l}\text { Birth of the sovereign } \\
\text { nation of Israel in } 1948 \\
\text { and start of diplomatic } \\
\text { relations with India }\end{array}$ \\
\hline My Study & Pali Buddhism & Judaism \\
\hline
\end{tabular}


As Nathan Katz illustrates, the very term "Indo-Judaic" reflects the diversity of the field. This field reconfigures the way different cultures and religions interact. First, the term "Hebrew-Sanskrit Studies" was appealing but left the field within the boundaries of textual traditions of Israel and India. Even though the terms "Hindu-Jewish" and "HinduJudaic Studies" were relatively more appealing, they still did exclude other non-Hindu but distinctively Indian religious traditions such as Buddhism and Jainism. Eventually, the term "Indo-Judaic" was deemed appropriate, as the term "Indo" is inclusive of all religious, cultural, linguistic traditions and systems, and geographical areas of the Indian sub-continent. It even includes "Indo-born" (=Indian-born) traditions as such now existing outside of the Indian sub-continent. ${ }^{39}$

The chart includes Pali Buddhism and Judaism parallel to each other in the second and third columns. Pali Buddhism, therefore, falls within the Indo-Judaic Studies. The following chart summarizes the research trajectories of Indo-Judaic Studies. The chart illustrates the research methodology of my study derived from Indo-Judaic Studies.

(Chart of Indo-Judaic Research Methodology is moved to the next page, owing to its size).

\footnotetext{
${ }^{39}$ See "Indo-Judaic Studies as a field" in Nathan Katz, "Introduction," Indo-Judaic Studies in the TwentyFirst Century A View from the Margin (New York: Palgrave Macmillan, 2007) pg. 2-4.
} 


\begin{tabular}{|c|c|}
\hline \multicolumn{2}{|c|}{$\begin{array}{c}\text { The Research Methodology } \\
\text { Data Revealed ("What-Aspect") and Data Examined ("What-So- } \\
\text { Aspect") }\end{array}$} \\
\hline $\begin{array}{l}\text { Data revealed (What-Aspect) } \\
\Downarrow \\
\Downarrow \\
\text { Data of Indo-Judaic typology of } \\
\text { Primordial Sainthood are revealed } \\
\text { from Pali Buddhism and } \\
\text { comparative data determined with } \\
\text { reference to Judaism } \Rightarrow \\
\text { (Research) } \Rightarrow\end{array}$ & $\begin{array}{c}\text { Significance of data examined } \\
\text { (What-So-Aspect) } \\
\Downarrow \\
\text { The data are examined. The } \\
\text { typology contextualizes the concept } \\
\Rightarrow \quad \text { of Primordial Sainthood } \\
\Downarrow \\
\Rightarrow \text { (Conclusion) }\end{array}$ \\
\hline
\end{tabular}

"What-Aspect" refers to the data revealed, and "What-So-Aspect," to the significance of those data. The data with regard to the notion of primordial sainthood are first revealed from within Pali Buddhism, and compared with similar data from within Judaism in order to derive comparative data and comparative terminology. The second step involves the examination of the data in order to carry out the contextualization process and to draw a conclusion of the religious notion involved, that is, primordial sainthood.

Barbara A. Holdrege, who, with Nathan Katz, has co-foundered and cocontributed immensely towards the Indo-Judaic Studies, explains the relevance of the Indo-Judaic approach to comparative research involving different religious traditions from different backgrounds. She maintains that the Indo-Judaic approach helps a researcher of comparative religion transcend what she calls the "politics of Eurocentric 
hegemony," that predominates the academic world. ${ }^{40}$ She concludes that Indo-Judaic Studies accords a comparative research the rightful place it deserves, as two or more religious traditions involved are not fit within a single theoretical framework, just as Eurocentric hegemony does, but considers each religious tradition a theoretical framework of itself. ${ }^{41}$ While scholars from Jewish background are motivated to explore the Indian civilization, Indian scholars like Ranabir Chakravarti ${ }^{42}$ explore the Jewish civilization.

${ }^{40}$ See Barbara A. Holdrege, "Beyond Hegemony," Indo-Judaic Studies in the Twenty-First Century A View from the Margin (New York: Palgrave Macmillan, 2007) pg. 78-92.

41 Ibid, pg. 89-90

${ }^{42}$ See Ranabir Chakravarti, "Reaching out to Distant Shores," Indo-Judaic Studies in the Twenty-First Century A View from the Margin (New York: Palgrave Macmillan, 2007) pg. 19-43. 


\section{CHAPTER THREE \\ THE TYPOLOGY}

The derivation of the typology illustrated here is a two-step process. First, by employing the "what-aspect" data are revealed from Pali Buddhism, and translated into English from the Pali. Second, the "what-so-aspect" is used to construct comparative terminology and compare the similar data revealed from within Judaism. Comparative terminology is required to create the theoretical grounds, appealing to both traditions.

(Due to its size the typology chart is moved to next page) 


\section{The Typology}

\section{Derivation of Primordial Saint}

STEP 1

STEP 2
Pali Buddhism
a)Pativedha 1
b)Pariyatti
c) Patipatti
d)Pativeda 2

Pali Buddhism

Pativeda 3

$+$

STEP 3

Pali Buddhism and Judaism

a)Primordial Saint

b) Revelation

c)Religion

d)Believers with

Vision of Revelation

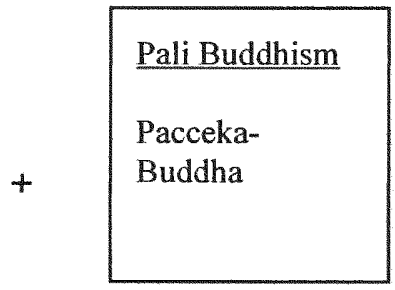

$\Downarrow$

\section{Derivation of Successive Sainthoods}

STEP 4

Pali Buddhism
a) Patideva 2 saints
b) Pariyatti saints
c) Patipatti saints

\section{$\Downarrow$}

$+$

Pali Buddhism and Judaism

a)Saints associated with

Buddha and Moses

b)Saints of Sacred Word

(Dhamma and Torah)

c)Saints of Ritualized Word 


\section{The Source Languages}

The source and the terminology of the typology are derived from a language that is only acceptable to Pali Buddhism; they are derived from Pali, the language of the Theravada Buddhist canon. Second, the original terminology needs to be translated and interpreted in order to derive terminology in English, which is universally acceptable to both religious traditions. The typology, therefore, can be given in comparative language.

\section{The Pali Terms and their Etymology}

All the Pali terms used in the typology are authentic canonical terms of Pali Buddhism. The first step of the typology contains four Pali terms, Pativedha, Pariyatti, Patipatti, and Pacceka-buddha. Here, I translate and interpret the said terms individually.

Put in the correct order they are used in the Pali canon, the first three terms must be in the sequence of Pariyatti, Patipatti and Pativedha. These three are always used in the Pali canon as a single group of words. The reason for their being used in the reverse order in my study is examined after the etymological description of all the three words. Derived from the root $\sqrt{\text { pati }}+$ vyadhi, to penetrate, comprehend, attain, become insightful, or to become knowledgeable, the term "pativedha" is synonymous with Nirvana or salvation in Pali Buddhism. ${ }^{43}$ The second term "pariyatt" is derived from the Pali root

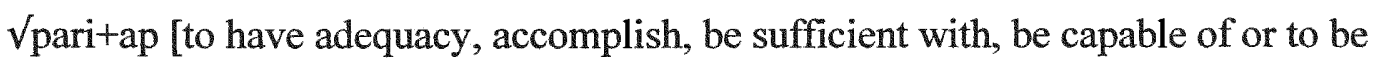
competent of]. It is used in terms of the holy texts or scripture, or the Buddha's

\footnotetext{
${ }^{43}$ T. W. Rhys Davids and William Stede, Pali - English Dictionary (New York: Laurier Books, Limited, 2001) pg. 399.
} 
teachings. ${ }^{44}$ The third term "patipatti" is derived from the Pali root $\sqrt{ }$ pati+pad [to conduct, practice, perform, or behave]. As a noun, it connotes "way," "path" or "method." The Pali canon uses it as a synonym of the Buddhist path to salvation. The study of pariyatti or the holy texts helps one tread the patipatti or the path to salvation. Hence, they are put in the order of pariyatti, patipatti, and pativedha. It is upon achieving pativedha that one becomes a saint. Therefore, the term "pativedha" occurs first in the typology. The step 1 and its adjacent step in the front mentions the term "pativedha" three times, each indicated in the numerical order. Pativeda 1 denotes the "primordial salvation" or "salvation of the person, who first discovered and revealed it to the world." Pativeda 2 denotes the "salvation of those, who follow the person of Pativedha 1. Pativeda 3 is way outside and, denotes the "salvation as achieved by somebody, who does not belong to the company of Pativedha 1 and Pativedha 2. While Pativedha 1 and 2 are mutually related in the manner the second depends on the first, the third is isolated.

The terms, "Buddha," "Arahanta" and "Pacceka-buddha" are the persons, who have achieved pativedha 1 , pativedha 2 and pativedha 3 respectively. While each "pativedha" is a "position," Buddha, Arahanta and Pacceka-buddha are "persons," who have achieved the "position." The term "Arahanta" is generally translated into English as Arahnat. English-speaking Buddhists, scholars of Buddhism and writers do not usually translate it, because the term "Arahant" is well known in the West.

${ }^{44}$ Ibid. 432 
Pacceka-buddha literally means 'one-way buddha. ${ }^{45}$ Etymologically, the term is derived from the combination of "pati" [direction] and "eka" [one]. Even though he discovers the path of salvation all by himself, he has no ability to show the path to others. He, therefore, is "buddha," and not "Buddha." He is not qualified to be a pioneer of salvation.

In Pali Buddhism there are no variations of salvation. The status of salvation is valued in higher or lower degrees, based on who discovers it first, and who relies on the first discoverer in order to discover it for himself. A Buddha is always the pioneer of pativedha in a new cycle of history. His position as the pioneer is explained in the next chapter.

The other two words in step 2,"Dhamma" and "Magga" are synonymous with "Pariyatti" and "Patipatti" respectively. The inclusion in the typology, of the terms, Pariyatti/Dhamma and Patipatti/Magga, is intended, as they contribute immensely towards the construction of the comparative terms in step 3. The step 4 repeats the original terms of step 1, pativeda 2, pariyatti and patipatti that function as the grounds of successive sainthoods.

\section{Comparative Terminology}

By the time the above-mentioned Buddhism-specific terminology is deconstructed on step 3, they are no longer Buddhist terms but universally comparative. The Buddha, who pioneers the path of salvation, becomes the first-ever holy person in the eyes of

\footnotetext{
${ }^{45}$ For an extensive analysis of the concept, see Angraj Chaudrary, "Concept of Paccekabuddha," Essays on Buddhism and Pali Literature, by Angraj Chaudrary, 1st ed. (Delhi: Eastern Book Linkers, 1994) pg. 107116.
} 
Buddhists. As the "first holy human person in a new cycle of history," he becomes the "primordial saint" to his followers. The body of his teaching that carries his experience of enlightenment, or Dhamma, becomes the "revelation." Pali Buddhism does not believe in a creator God. Revelation, therefore, is a 'self-revelation.' The way to salvation becomes an institutionalized system called religion. The followers, who follow his already discovered revelation, are the world or society. He leads the world, up until the coming of another primordial saint. This comparative reduction of the Pali Buddhist terminology helps us see the Buddha's similarity to Moses in Judaism.

\section{Siddhartha the Buddha and Moses the Prophet: The Comparative Case}

My purpose here is not to study the historicity of Siddhartha and Moses but to contextualize the historical Siddhartha as the Buddha, and Moses as the Prophet. Each personality here is viewed as grounded in a historical/theological dichotomy.

Siddhartha lived in North India in the $6^{\text {th }}$ century BCE. ${ }^{46}$ His father was the ruler of the kingdom of Sakyas, a royal clan that was native to what is now modern Nepal. His mother was queen Maya. He was married at age sixteen, according to the prevalent custom of the land. His wife was Yasodhara from the Koliya dynasty that ruled a neighboring kingdom. He had all worldly comfort he could enjoy in his royal life. But, having pondered over different universal human sufferings he happened to witness in

\footnotetext{
${ }^{46}$ For an extended biography of Siddhartha, see Walpola Rahula and Paul Demieville, What the Buddha Taught (New York: Grove P, 1987).
} 
society, he left royal life and became a wondering ascetic. He would remain so for six years, striving to find salvation.

After six years of rigorous ascetic practice, he left that path. He became the Buddha by practicing what is called the "middle path. ${ }^{47}$ Here, it is noteworthy that Pali Buddhism no longer calls him Siddhartha but "the Buddha." Theravada Buddhologists or Buddhist theologians separate Buddha from Siddhartha. The saintliness is not within Siddhartha but within the Buddha.

The same dichotomy can be used in the case of Moses. Biblical scholars disagree dramatically in their views of the historicity of Moses. ${ }^{48}$ Solomon Nigotian suggests that he was perhaps born around $13^{\text {th }}$ century $\mathrm{BCE} .^{49}$ Soon after his birth, his mother hid him at home for three months, as the Egyptian government did not tolerate the growing Jewish population. The government ordered all male babies born to Jewish families killed. Like Siddhartha, Moses witnessed numerous universal human problems of his time. ${ }^{50}$ Judaism teaches that God gave the revelation to Moses on Mount Sinai. ${ }^{51}$ God declared: "If there is a prophet among you, I the Lord, make myself known to him in a vision; I speak to him in a dream. Not so with my servant Moses; he is entrusted with all

\footnotetext{
${ }^{47}$ Pali: Majjhima Patipada. This is a path between "self-indulgence" (Pali: kamasukhallikhanuyoga) or extreme luxury, and "self-mortification," (Pali: attakilamathanuyoga) or extreme asceticism.

${ }^{48}$ Solomon A. Nigosian, World Religions: A Historical Approach (Boston: Bedford/Saint Martin's, 2007) pg. 322 .

${ }^{49}$ Ibid.

${ }^{50}$ For an extensive historical account of Moses, see Elias Auerbach, Moses, English Translation ed. (Detroit: Wayne State UP, 1975).

${ }^{51}$ See Elias Auerbach, Moses, English Translation ed. (Detroit: Wayne State UP, 1975) pg. 144-148
} 
my house. With him I speak mouth to mouth clearly and not in dark speech; and he beholds the form of the Lord. ${ }^{52}$

In Exodus 33:11, Moses is said to have spoken to God 'face to face as a man speaks to his friend. ${ }^{53}$ As the revelation to Moses is believed to be "unique. ${ }^{54}$ God only chose Moses to receive the Revelation, based on Moses' qualification that is of no question from the Indo-Judaic approach. As one from the Pali Buddhist background, I see Moses as the first and best human personality to hear the revelation. In scholarly language, the founder of a religion is a human figure. Buddha is the founder of Pali Buddhism. Even though Judaism does not have a founder, the human personality that can be regarded as the pioneer of Jewish religion is none other than Moses. The religion is derived from the revelation. The revelation is either discovered or received by a human personality. Buddha and Moses presented the humanity with the Revelation. In terms of the fact that Buddha is the primordial saint, Moses is the primordial saint of Judaism. A scholar of Judaism may not agree to the fact that Moses is indeed the primordial saint. He can even question as to whether Moses is a saint. In my effort to see the Jewish parallel of the Buddhist notion primordial saint, it is only Moses that I see as suitable for comparison, as a scholar from the "Indo" background.

\footnotetext{
${ }^{52}$ Dan Cohn-Sherbok, Judaism: A Short History (Minneapolis: Oneworld Publications, 1999) 11-12

${ }^{53}$ Dan Cohn-Sherbok explains the account of Moses encountering God, as it is depicted in Exodus 33.11. See Dan Cohn-Sherbok, Judaism: A Short History (Minneapolis: Oneworld Publications, 1999) 11-89 ${ }^{54}$ Ibid
} 


\section{Successive Sainthoods of Pali Buddhism}

The canonical Pali Buddhism ${ }^{55}$ uses the terms, pariyatti, patipatti and pativedha, to denote different doctrinal concepts. But, in commentarial Pali Buddhism ${ }^{56}$, these terms have gone through a huge etymological transformation. The original meaning of each term has evolved to a great extent. In the Pali commentaries the said terms are used as adjectives to the term "sasana," hence "pariyatti sasana," "patipatti sasana," and "pativedha sasana," which mean three different layers of Pali Buddhism.

In modern Theravada, these three layers function as a tri-layered institution of Pali Buddhism. Before describing the terms, a description of the very term "sasana" is required here. A description as such helps us understand the said etymological transformation. The Dhammapadatthakatha, or the Commentary to the Dhammapada, ${ }^{57}$ for instance, mentions the terms "pariyatti sasana," "patipatti sasana" and "pativedha sasana" in terms of "threefold dispensation or threefold religious system of the Buddha." The Mahaniddesa, another post-canonical Pali work that has occupied a canonical position, mentions the three terms with the same meaning. ${ }^{58}$

\footnotetext{
${ }^{55}$ Canonical Pali Buddhism is the type of Buddhism as depicted in the Pali canon.

${ }^{56}$ Commentarial Pali Buddhism is the type of Buddhism as depicted in the Pali atthakathas or commentaries, most of which were written in Sri Lanka explaining the doctrines of the Pali canon.

${ }^{57}$ H C Norman, ed., The Dhammapadatthakatha, First ed., vol. IV (London: Pali Text Society, 1914) pg. 46-47.

${ }^{58}$ De La Vallee Poussin and Edward J. Thomas, eds., The Mahaniddesa, Reprint ed. (London: Pali Text Society, 1978) pg. 110-112.
} 
The institutionalized Theravada or Pali Buddhism today clearly functions as a tri-layered religious system. The pariyatti layer beholds the monastic experts on the Dhamma as its holiest personalities. Monastics playing socio-cultural and geo-political roles are beheld as the holiest personalities by the patipatti layer.

The last and highest one, pativedha layer beholds arahants and other semienlightened monastics ${ }^{59}$ as the holiest personalities. Below is a chart illustrating this trilayered Pali Buddhism and its role as the grounds of successive sainthoods. The chart gives adequate understanding of the data illustrated in the next chart.

\begin{tabular}{|c|c|c|}
\hline The Original Term & $\begin{array}{l}\text { The Original Term after } \\
\text { Etymological Transformation }\end{array}$ & $\begin{array}{l}\text { Corresponding Layer } \\
\text { Of successive Sainthoods }\end{array}$ \\
\hline 1)Pativedha 2 & 1)Pativedha 2 Saint & $\begin{array}{l}\text { 1)Saints associated with } \\
\text { Primordial Saint }\end{array}$ \\
\hline 2)Pariyatti & 2)Pariyatti Saint & 2)Saint of Sacred Word \\
\hline 3)Patipatti & 3)Patipatti Saint & 3) Saint of the People \\
\hline
\end{tabular}

The above chart includes the data from Step 4 of the typology explained in the previous chapter. Step 4 illustrates the three successive sainthoods of the above chart in

\footnotetext{
${ }^{59}$ The Atthaka Nipata of the Anguttara Nikaya mentions four fairs (eight) persons of enlightenment, who are none other than those who have tread the path of stream-entering (sotapanna magga), who achieved the fruit of the treading of the path of stream-entering (sotapanna phala), who have tread the path of oncereturning (sakadagami magga), who have achieved the fruit of the treading of the path of once-returning (sakadagami phala), who have tread the path of non-returning (anagami magga), who have achieved the fruit of the treading of the path of non-returning (anagami phala), who have tread the path of complete enlightenment (arahanta magga), and who have achieved the fruit of the treading of the path of complete enlightenment (arahanta phala). The last person is an Arahnat. For further detail, see the section of Atthaka Nipata in R. Morris, ed., The Anguttara Nikaya, 2nd ed., vol. I (London: Pali Text Society, 1961).
} 
comparative terminology. The following chat is a supplemental to the main typology. It was not included in the main typology, given the fact that purpose of it was to contextualize the notion of primordial sainthood.

\begin{tabular}{|l|l|l|}
\hline $\begin{array}{l}\text { Comparative Terms of } \\
\text { Successive Sainthoods }\end{array}$ & $\begin{array}{l}\text { Pali Buddhist Successive } \\
\text { Sainthoods specified }\end{array}$ & $\begin{array}{l}\text { Jewish Successive } \\
\text { Successive Sainthoods } \\
\text { specified }\end{array}$ \\
\hline $\begin{array}{l}\text { (a)Saints associated with } \\
\text { Buddha and Moses }\end{array}$ & $\begin{array}{l}\text { (a)Arahants, } \\
\text { contemporary with } \\
\text { Buddha as well as latter- } \\
\text { day, other semi- } \\
\text { enlightened personalities, } \\
\text { contemporary with } \\
\text { Buddha as well as latter- } \\
\text { day, and pacceka-buddhas }\end{array}$ & $\begin{array}{l}\text { central prophets in Torah } \\
\text { community) } \\
\text { day prophets }\end{array}$ \\
(b)Saints of Sacred Word \\
(Dhamma and Torah)
\end{tabular}

Now, we will describe the data in the second chart with reference to the first chart in this chapter. The Successive Sainthoods of Pali Buddhism are understood as depicted in Sri Lankan Theravada. The second chart includes some new terms, "Bhanaka," "Atthakathacari," "Villlage Monks," "Tantric Theravada Monks," "Rabbis," "Tsaddiqim," "Kabbalists," and "Rebbes." 
Bhanaka, which literally means the "talker" or "chanter" or "one who declares" were the keepers or preservers of the Pali Buddhist oral tradition. ${ }^{60}$ Atthakathacaris were the commentators to the Pali canon. ${ }^{61}$ Village Monks are the Buddhist monastics live their life in village, or with the society, as opposed to the forest-dwelling monks.

Tantric Theravada Monks are those who use the Dhamma in ritualized Tantric for healing and astrological purposes. A Rabbi is a Jewish spiritual authoritative figure, which is specialized in the Jewish canon. The roles of a Zaddik or Tsaddiq (plural: Tsaddiqim) and a Kabbalist involve Jewish mystical practice for purposes of healing and blessing. Rebbe, a Yiddish word that means master, teacher or mentor, lead local Jewish communities. The Jewish counterpart of the Pali Buddhist saint of Ritualized Word is discussed towards the end of the chapter, with reference to Moroccan Judaism.

Pativedha 1 saints, Pariyatti saints and Patipatti saints in the third cage of the first chart above are specified in terms of their roles in the second chart above. Re-indicated in the first column of the second chart, they are the figures who were contemporary with Buddha and Moses as well as Buddhist pacceka-buddhas and Jewish prophets, who have heard the revelation through the Jewish history. The second and the third columns indicate the role specifications of the individual successive sainthoods. The type (a) received the first hand experience of revelation from Buddha and Moses. Of the Jewish case, even though Judaism does not clearly say who they were, Pali Buddhism has a

\footnotetext{
${ }^{60}$ T. W. Rhys Davids and William Stede, Pali - English Dictionary (New York: Laurier Books, Limited, 2001).

${ }^{61}$ Ibid
} 
primary list of eighty great disciples ${ }^{62}$ Pariyatti saints are those who have been, and still are, responsible for the preservation of the revelation.

The type (b), in the second chart deserves a bit longer description, given their unparalleled role of preserving the Dhamma and Torah over the centuries as oral traditions, and writing commentaries and interpretations in order to meet the popular demand in the time periods they lived. In the Buddhist case, Bhanakas kept the Dhamma, the revelation, by means of memorization over the Buddhist history, up until the Dhamma came to be written in book form in Sri Lanka during the reign of King Vatta Gamini Abhaya (104 BCE-76 BCE). ${ }^{63}$ During the history of oral tradition, political turmoil and perpetually volatile political situations in India and Sri Lanka either claimed the lives of some Bhanakas, or forced them into exile in different regions of India and Sri Lanka. The Atthakathacaris, the greatest of whom was Buddhaghosa, had a dual task of investigating the consistency of the oral teachings, and of properly defining and interpreting the Dhamma in order to meet the popular demand of the time they lived. ${ }^{64}$ At the First Buddhist Council help three months after the demise of the Buddha, different senior Arahants and their students were assigned with the task of keeping or preserving the Dhamma as an oral tradition.

\footnotetext{
${ }^{62}$ The Etadaggapali of the Pali Anguttara Nikaya mentions the eighty great disciples, who Buddha declared as expertise on different precepts and practices of his assembly. Of them Ananda, Buddha's personal attendant and Treasurer of Dhamma (Pali: Dhamma-bhandagarika), was still unenlightened, and Daruciriya, an arahant but a layperson, are noteworthy. For further detail, see the section of Etadaggapali in R. Morris, ed., The Anguttara Nikaya, Second ed., vol. I (London: Pali Text Society, 1961).

63 Adikaram E W, Early History of Buddhism in Ceylon, First ed. (Colombo: M D Gunasena, 1953) pg. $71-76$

${ }^{64}$ Adikaram give a list of Pali Buddhist commentators and their works. See Adikaram E W, Early History of Buddhism in Ceylon, First ed. (Colombo: M D Gunasena, 1953) pg. 9-11.
} 
The oral tradition virtually ended with the writing of the Dhamma on palm leaves during the reign of Vatta Gamini Abhaya. ${ }^{65}$ Adikaram explains the harsh situations the Bhanakas encountered over the centuries of oral tradition. ${ }^{66}$ In the Jewish case, Rabbis preserved the Torah at the risk of their lives, and contributed towards the growth of Judaism with the compilation of a vast rabbinic literature that plays the role of commentaries and interpretations. With the destruction of the First Temple in $586 \mathrm{BCE}$, and that of the Second Temple in $70 \mathrm{CE}$, the Jewish Saints of Word had to risk their lives in order to preserve the Torah. The role preservation has made the said Buddhist and Jewish counterparts depicted in the second chart a saintly position.

The saints of the People have the role of serving their communities, by dint of which they become communal or popular saints. They do not necessarily use the canonical languages of Pali and Hebrew but perform their roles either in colloquial or local languages or in a hybrid of both. This type of successive saints has contributed towards the strengthening of the foundations of popular Pali Buddhism and popular Judaism.

\section{Successive Sainthoods of Judaism}

Just as Pali Buddhist successive sainthoods are understood in as depicted in Sri Lankan Theravada context, the Jewish case here is understood in the contexts of Hassidic Movement and Moroccan Judaism.

\footnotetext{
${ }^{65} \mathrm{Ibid}$

${ }^{66}$ Adikaram give a list of Pali Buddhist commentators and their works. See Adikaram E W, Early History of Buddhism in Ceylon, First ed. (Colombo: M D Gunasena, 1953) pg. 9-11.
} 
Hassidic Movement emerged in the second half of the eighteenth century beginning in Podolia in the Ukraine and then spreading to other parts of Eastern Europe, including central Poland, Galicia, Hungary, Belorussia, and Lithuania. The founder of the movement is considered to be Israel Baal Shem Tov, known as Besht. In fact, he appears to have been one of several itinerant preachers characterized by ecstatic behavior and possessing the ability to perform miracles through use of the divine names. ${ }^{67}$ This position made him a saint in the eyes of his disciples. The period of the most intense flourishing of Hassidism was between 1773 and 1815, when the disciples of Dov Baer Mezhirech, successor to Israel Baal Shem Tov, helped to spread the movement by establishing centers throughout eastern Europe.

Hassidism provided an alternative way of religious leadership to the public or communities, in the form of "Tzaddik," meaning "righteous one." A tzaddik is always a charismatic personality that makes him the sole authority in religious and mundane matters of the community that follows his spiritual leadership. ${ }^{68}$ Israel Baal Shem Tov taught that "devekut" or communion with God could be maintained in the context of social relations. The concept of devekut has continued to have a profound influence on Jewish mysticism, culminating with the widespread use of the term in the Hassidic literature of the eighteenth and nineteenth centuries. Hassidism holds devekut as an ideal for all people. I $\mathrm{n}$ order to achieve that, any mundane act, even if profane, can become a

\footnotetext{
${ }^{67}$ HarperCollins dictionary of religion (San Francisco: HarperSanFrancisco, 1995) pg. 410. ${ }^{68} \mathrm{Ibid}$
} 
means for attaining a state of cleaving to God. ${ }^{69}$ A tzaddik, or Hassidic saint, would help his community achieve that. The ground of Hassidism was prepared by the formation of various mystic cycles characterized by a distinctive pattern of religious asceticism. These mystic cycles were none other than those of Hassidic saints. The tzaddik stands between heaven and earth, in other words, the channel between God and the people, and the foundation of the world. ${ }^{70}$

According to Hassidism, man is a source of holiness. ${ }^{71}$ As we understand Moses as the first human being to be so, others successive saints have continued to be a source of holiness. Hassidism teaches that God created the heavens and the earth, the stars, the mountains, and the animals, but he breathed his spirit into man alone. The righteous man was the object of creation, and he occupies a superior place in the world of creation. A tzaddik, or a holy man, remains saintly. ${ }^{72}$ Scholem calls him "saint-mystic."73

A Tzaddik in general is both a mystic and a scholar. He, therefore, is both an Saint of the Word, and a Saint of the People. An ample example of this dual role is Rabbi Yaakov Yosef of Polnoy. A prominent tzaddik himself, he was the first and is still to this day the most important Hassidic writer. ${ }^{74}$ He set down and expounded in so

\footnotetext{
${ }^{69}$ Ibid, 312

${ }^{70}$ Samuel H. Dresner, The Zaddik: The Doctrine of the Zaddik According to the Writings of Rabbi Yaakov Yosef of Polnoy (New York: Abelard-Schuman, 1974) pg. 117.

${ }^{71}$ Ibid, 122

${ }^{72}$ Ibid

${ }^{73}$ Samuel H. Dresner, The Zaddik: The Doctrine of the Zaddik According to the Writings of Rabbi Yaakov Yosef of Polnoy (New York: Abelard-Schuman, 1974) pg. 18.

${ }^{74}$ Ibid
} 
masterly a fashion the teachings of Israel Baal Shem Tov, his teacher and the founder of Hassidism. While continuing to be the channel between God and the world, a tzaddik preserves the Revelation by interpreting it in a way his community comprehends it.

The Moroccan case is an ample example of the Sainthood of the People. In Morocco there is trend of saint veneration among the local Jewish communities. Issachar Ben-Ami has done extensive research on the saint veneration among the Jewish communities in Morocco. ${ }^{75}$ In a ten-year long fieldwork, he has identified 656 Jewish saints, 25 of them women. ${ }^{76}$ He mentions a five major categories of source that conduced to his research, 1) folktales, particularly legends about saints transmitted from generation to generation; 2) descriptions of miracles -some of which are known to many Moroccan Jews and therefore can be considered folk material, and some of which are personal miracles experienced by the informants; 3 ) dreams, most often individual, personal ones, although some of them are familiar and widespread among Moroccan Jews in general; 4) descriptions of experience primarily associated with the ziyara and hillulah in homage to saints, but also related to various aspects of daily life that express affinity with the revered figure; and 5) a few historical traditions. ${ }^{77}$

The list of the Moroccan Jewish saints is too long to mention here. But, I find it applicable here to mention of some terms corresponding the Moroccan Jewish saints. For female Jewish saints, the term "saddiqah" or "tsaddiqah" is used. This is the feminine

\footnotetext{
${ }^{75}$ See Issachar Ben-Ami, Saint veneration among the Jews in Morocco (Detroit: Wayne State UP, 1998).

${ }^{76}$ Issachar Ben-Ami, Saint veneration among the Jews in Morocco (Detroit: Wayne State UP, 1998) pg. 13

${ }^{77}$ Ibid, pg. 15
} 
form of the title "tsaddiq." Another widespread term among Jews is "baba," meaning "father." This would seem to be an affectionate name usually given to saints during their lifetime.

The Moroccan Jews frequently add titles such as "zizi," meaning "my beloved," and "hbibi," meaning "my dear." Jews in Southern Morocco use the term "el-"naya," meaning "of "Providence." Jews of Draa use the term "el-ghassi," meaning "community," "crowd," and "congregation." This is because a saint is venerated and regarded as the patron of a Jewish community. ${ }^{78}$ The most widespread term for a Jewish female saint is "lalla," meaning "lady" in Berber. In one case, two titles are combined in the name "Lalla Tsaddiqah" buried in a Moroccan city called Imi n'Timouga. In two other instances, both titles are prefixed to the name of the saint, Lalla Sol Ha-Tsaddiqah and Lalla Miriyam Ha-Tsaddiqah. The name of one female saint bears the Hebrew term "imma," meaning "mother, Imma Esther, and the name of another, the term Arabic term "setti," meaning "lady." Combined together the female saint is called Lalla Setti BenSasso. Occasionally, other titles are added to the names of Jewish saints, for instance, "sba," meaning "lion," or "sba'el-kebir," meaning "great lion," or "sba'el'ziz," meaning "beloved lion." 79

Most Jewish saints in Morocco are recognized as saints, and are venerated after their death. Exemplary behavior or exceptional erudition exhibited by certain individuals

\footnotetext{
${ }^{78}$ Issachar Ben-Ami, Saint veneration among the Jews in Morocco (Detroit: Wayne State UP, 1998) pg. 21 ${ }^{79}$ Ibid.
} 
during their lifetimes prepared the grounds for the bestowal of sainthood after death. Some achieved sainthood while still alive. ${ }^{80}$

To generalize from the Moroccan popular Jewish context, a saint manifests himself or herself primarily through the performance of miracles or by exemplary behavior. This can happen either through a dream or by the occurrence of some extraordinary event at the time of death or by the occurrence of some extraordinary event at the time of death or burial. ${ }^{81}$

It is concluded here that the concept of primordial sainthood is contextually strengthened and validated by the concept of successive sainthoods. Viewed from this popular Jewish context, Moses was chosen by God, because of an extraordinary character that God himself saw in Moses. Moses' passing down of the revelation to the human world is indeed an extraordinary behavior. The typology has created the grounds for the fact that one can be a saint, even though one is not as enlightened as the Buddha, or has not directly encountered God as Moses did.

\footnotetext{
${ }^{80}$ Ibid

${ }^{81}$ Ibid
} 


\section{CONCLUSION}

After a revisit to the available modern scholarly theories of both Pali Buddhist and Jewish sainthood studies, I have found that there had never been any comparative research on Theravada Buddhist and Jewish sainthoods. While Tambiah's theory of Linked Foci has marked a turning point in the study of Pali Buddhist sainthood, it has not provided adequate grounds for a study in comparative sainthood, owing to the fact that Tambiah's approach is Eurocentric/Orientalist. The theory of Linked Foci provided me with some background for constructing the typology of primordial saint in a Pali Buddhist context. Cohn's groundbreaking theory of "sainthood in Periphery" contextualizes a Jewish notion of sainthood as an ideal rather than a position of an individual. He has created the initial grounds for possible research in Jewish sainthood. Pali Buddhism recognizes individuals as holy because of the position of saintliness they hold. However, it sees a fine line between the position and individual.

Both Tambiah and Cohn show a fine line between sainthood itself and the individual person that holds it. The typology has contextualized a distinction between the historical figure, Siddhartha, and his theological position, Buddha. In the Jewish case, it has contextualized a distinction between the historical figure, Moses, and his theological position of Prophet.

The derivation of the typology has been possible, since the Indo-Judaic approach was employed as the theoretical approach. The Eurocentric/Orientalist approach fails to derive the typology, because of its reductionist nature. While the Eurocentric approach delineates the canonical/classical layer and popular layer of Pali Buddhism, the Indo- 
Judaic approach sees both layers as a single flow of continuity. Subsequently, the IndoJudaic approach has helped me deal with what would otherwise have been a methodological problem. A methodological problem did not arise, as the entire Pali Buddhism was seen in light of the 'one-wheel theory,' as opposed to the Eurocentric/Orientalist 'two-wheel theory.'

The notion of successive sainthoods validates and further strengthens the concept of primordial sainthood. If not for Buddha and Moses, a notion of a pioneering or primordial saint is impossible. In a Eurocentric/Orientalist model, the derivation of successive sainthoods is impossible, as it only includes the enlightened Buddhist in sainthood, and excludes the successive sainthoods. Tambiah's linked foci are an ample example. 


\section{BIBLIOGRAPHY}

Aronson, Harvey B. Love and Sympathy in Theravada Buddhism. Delhi: Motilal Banarsidass Pub, 1980.

Ben-Ami, Issachar. Saint veneration among the Jews in Morocco. Detroit: Wayne State UP, 1998.

Chaudrary, Angraj. "Concept of Paccekabuddha." Essays on Buddhism and Pali Literature. By Angraj Chaudrary. 1st ed. Delhi: Eastern Book Linkers, 1994.

Dresner, Samuel H. The Zaddik: The Doctrine of the Zaddik According to the Writings of Rabbi Yaakov Yosef of Polnoy. New York: Abelard-Schuman, 1974.

E W, Adikaram. Early History of Buddhism in Ceylon. First ed. Colombo: M D Gunasena, 1953.

Gombrich, Richard, and Gananath Obeysekera. Buddhism Transformed: Religious Change in Sri Lanka. Princeton, NJ: Princeton UP, 1988.

Gombrich, Richard F. Buddhist precept and practice traditional Buddhism in the rural highlands of Ceylon. London: Kegan Paul International, Distributed by Columbia UP, 1995.

Goonatilake, Susantha. Anthropologizing Sri Lanka A Eurocentric Misadventure. New York: Indiana UP, 2001.

HarperCollins dictionary of religion. San Francisco: HarperSanFrancisco, 1995.

Hunt, M., and C A F Rhys Davids, eds. The Anguttara Nikaya. Vol. VII. London: Pali Text Society, 1910.

Kapferer, Bruce. Celebration of demons exorcism and the aesthetics of healing in Sri Lanka. Providence, R.I., USA: Berg, Smithsonian Institution P, 1991.

Katz, Nathan, and Stephen D. Sowle. "Theravada Buddhism and Marxism in the Postwar Era." Movements and Issues in World Religions: A Sourcebook of Developments since 1945. Ed. Charles Wei-hsun and Gerhard E. Spiegler. New York, Westport, CT, and London: Greenwood P, 1987. 418-61.

Katz, Nathan. Indo-Judaic Studies in the Twenty-First Century A View from the Margin. New York: Palgrave Macmillan, 2007. 
Katz, Nathan. Buddhist Images of Human Perfection The Arahant of the Sutta Pitaka Compared with the Bodhisattva and the Mahasiddha. Delhi: Motilal Banarsidass Pub, 2004.

Kieckhefer, Richard and Bond, George D., ed. Sainthood - Its Manifestations in World Religions. New York: University of California P, 1992.

Malcolm, Hamilton,. Sociology of religion theoretical and comparative perspectives. London: Routledge, 1995.

Morris, R., ed. The Anguttara Nikaya. 2nd ed. Vol. I. London: Pali Text Society, 1961.

Nigosian, Solomon A. World Religions : A Historical Approach. Boston: Bedford/Saint Martin's, 2007.

Norman, H C, ed. The Dhammapadatthakatha. First ed. Vol. IV. London: Pali Text Society, 1914.

Poussin, De La Vallee, and Edward J. Thomas, eds. The Mahaniddesa. Reprint ed. London: Pali Text Society, 1978.

Rahula, Walpola, and Paul Demieville. What the Buddha Taught. New York: Grove P, 1987.

Ray, Reginald A. Buddhist Saints in India : A Study in Buddhist Values and Orientations. New York: Oxford UP, Incorporated, 1999.

Reynolds, Frank. "The Two Wheels of Dhamma: A Study of Early Buddhism." The Two Wheels of Dhamma: Essays on Theravada Tradition in India and Ceylon. Vol. Three. Chambersburg, Pennsylvania: American Academy of Religion, 1972. 6-30.

Rhys Davids, T. W., and William Stede. Pali - English Dictionary. New York: Laurier Books, Limited, 2001.

Schechter, Solomon. Studies in Judaism: Essays on Persons, Concepts, and Movements of Thought in Jewish Tradition. 3rd Reprint ed. Atheneum, NY: The Jewish Publication Society of America, 1970.

Smith, Bardwell L., ed. The Two Wheels of Dhamma: Essays on Theravada Tradition in India and Ceylon. Vol. Three. Chambersburg, Pennsylvania: American Academy of Religion, 1972.

Smith, Jonathan, and 1972 \& American Academy of Religion Staff. The HarperCollins Dictionary of Religion. Ed. William S. Green. New York: Harper San Francisco, 1998. 
22 Feb. $2009<$ http://www.worldwisdom.com>.

Von, Hinuber O., and K R Norman, eds. The Dhammapada. London: Pali Text Society, 1994.

Weber, Max. The Religions of India. Glencoe, Ill: Free P, 1958. 
22 Feb. $2009<$ http://www.worldwisdom.com>.

Von, Hinuber O., and K R Norman, eds. The Dhammapada. London: Pali Text Society, 1994.

Weber, Max. The Religions of India. Glencoe, Ill: Free P, 1958. 